肺癌完全切除により角化性紅斑が改善した Bazex 症候群の 1 例

\author{
篠原 周一*1, 鬼塚 貴光*1, 深津 藤子*2 \\ 町田 和彦*3，松尾 正樹*3，菅谷 将一*1
}

\begin{abstract}
要 旨
皮虑所見は腫瘍随伴症候群のひとつとして重要であるが，しばしばその背景に存在する悪性腫瘍が見落とされ，対症療法 のみで経過をみられることがある. 今回, 肺癌完全切除により 3 年以上続いていた角化性皮膚炎が治癒した Bazex 症候群の 1 例を経験したので報告する。症例は 77 歳男性, 3 年前から顔面, 手指, 頸項部に角化性紅斑を認め, 経時的に増悪し近医 皮膚科で対症療法をされていた，検診のレントゲンで胸部異常陰影を指摘され，生検にて非小細胞肺癌と診断され，右上葉

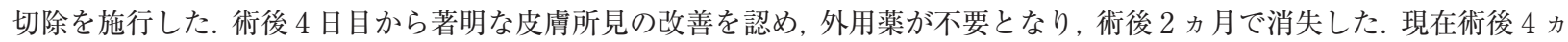
月再発なく皮膚症状も再燃なく経過している.
\end{abstract}

索引用語：Bazex 症候群, 傍腫瘍症候群, 紅斑, 角化, 肺癌

Bazex syndrome, paraneoplastic syndrome, erythema, keratosis, lung cancer

はじめに

腫瘍随伴症候群はまれである ${ }^{1}$ が, 背景に潜む悪性腫瘍 を早期発見するために有用である。 とりわけ腫瘍随伴性 皮膚病変は特異的 2 であり, 皮膚科以外の領域の医師も見 逃してはならない身体所見である．角化性紅斑を特徴と するBazex 症候群はまれな病態であるが, 呼吸器外科医 も熟知していなければならない.

今回, 肺癌完全切除により 3 年以上続いていた角化性 皮膚炎が治癒した Bazex 症候群の 1 例を経験したので 報告する。

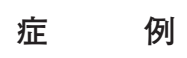

患 者: 77 歳, 男性.

主 訴：なし。

既往歴：特記事項なし.

生活歴：喫煙歴 20-77 歳, 30 本/日 $\times 57$ 年間.

\footnotetext{
${ }^{* 1}$ 中部万うさい病院呼吸器外科

${ }^{* 2}$ 同 皮膚科

*3同 呼吸器内科

原稿受付 2017年10月10日

原稿採択 2017年11月 1 日
}

職業歴 木材・プラスチック加工業.

現病歴：X-3 年から鼻尖部, 頸項部, 両手指に皮疹が出 現し，近医にて外用薬を処方されていた，徐々に皮膚症 状が増悪し，外用剤で経過をみていたが，改善がみられ なかった． $\mathrm{X}$ 年に検診で右上肺野に腫瘤影を指摘され， 精査の結果, 右上葉非小細胞肺癌と診断された。手術目 的に当院当科紹介となった.

入院時現症：身長 $164 \mathrm{~cm}$, 体重 $57 \mathrm{~kg}$, 皮膚は前額部, 鼻尖部, 背部, 耳介に色素沈着と鱗屑を伴う紅斑を認め, 両手指に搔痒を伴う落首性紅斑を認めた（Fig. 1).

入院時血液検查 : WBC $12,000 / \mu \mathrm{l}, \mathrm{Hb} 14.0 \mathrm{~g} / \mathrm{dl}$, 血小 板 26.4 万, CRP $2.11 \mathrm{mg} / \mathrm{dl}$, CEA $5.2 \mathrm{ng} / \mathrm{ml}$, SCC $2.6 \mathrm{ng} /$ ml, CYFRA $7.1 \mathrm{ng} / \mathrm{dl}$, NSE $6.7 \mathrm{ng} / \mathrm{dl}$, Pro-GRP $51.1 \mathrm{ng} /$ dl.

胸部 $\mathrm{X}$ 線所見：右上肺野に $5 \mathrm{~cm}$ の腫瘤影を認めた.

胸部 CT 所見：右上葉の $\mathrm{S}^{2} に 5.7 \times 5.5 \mathrm{~cm}$ 大の辺縁不 整な腫瘤を認めた (Fig. 2). 内部は一部に低吸収域を含ん でいた，明らかなリンパ節の腫大は認めず.

術前診断：気管支鏡を行い, 右上葉 B2 入口部に腫瘍 を同定し経気管支生検を施行した結果，肺扁平上皮癌の 診断(右上葉肺扁平上皮癌 cT3N0M0 Stage IIB) を得た. また術前に頸項部より皮膚生検を行い，悪性所見はなく 

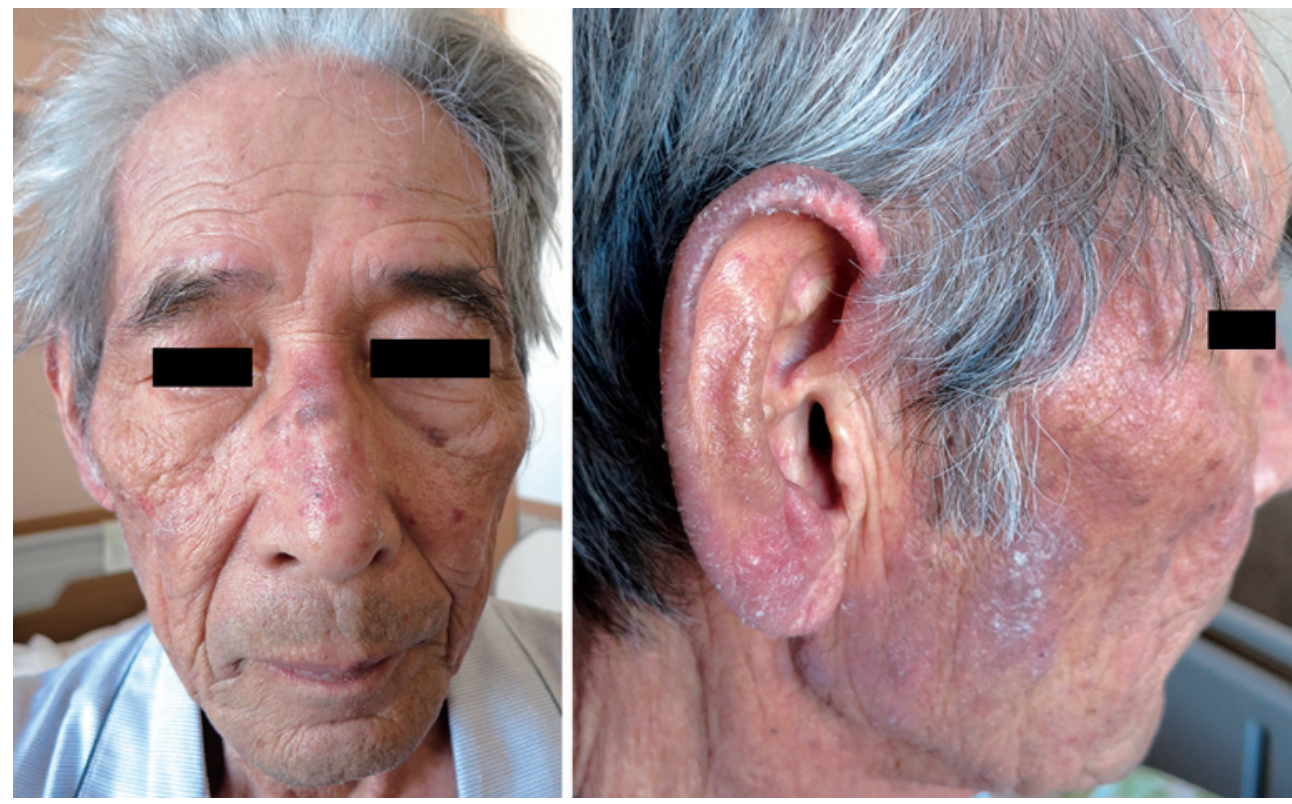

Fig. 1 Skin manifestation before surgery

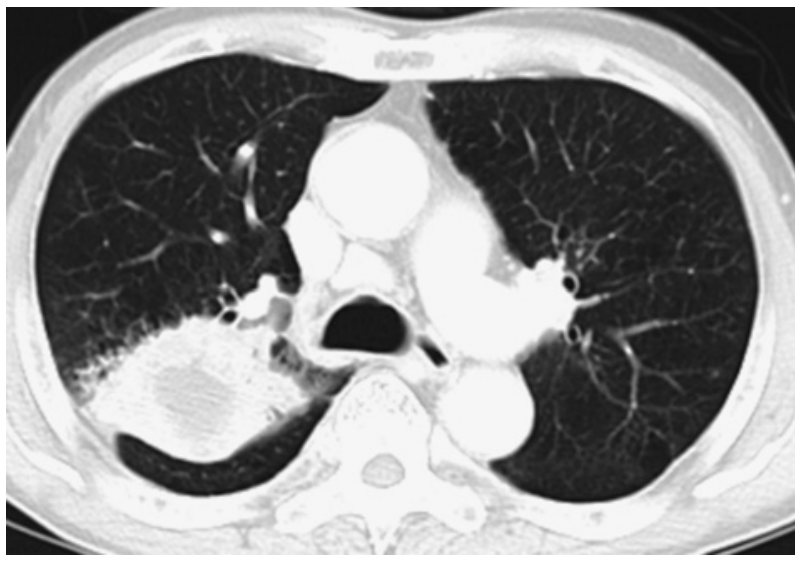

Fig. 2 Chest computed tomography shows a tumor of 5.7 $\mathrm{cm}$ with obstructive pneumonia in the upper lobe.

錯角化を伴う炎症性変化を認めた（後述）.

手術所見 : 左側臥位, 前側方切開, 第 4 肋間開胸で手 術を行った。腫瘍は $\mathrm{S}^{2}$ に存在し, 上葉は閉塞性肺炎と なっており, 腫痬が $\mathrm{S}^{6} に$ 浸潤している可能性があり, 上 中葉間も分葉不全だった。肺門部も閉塞性肺炎の影響で 炎症性の癒着を認め, 剥離が困難だった. 肺門先行で $\mathrm{V}^{1-3}$ から切離し, 肺動脈本幹を確保して $\mathrm{A}^{1+3}, \mathrm{~A}^{2}$ を前方 から切離し, 上葉気管支を切離し, 術中迅速病理診断で 断端の陰性を確認した。葉間を自動縫合器で切離し $S^{6}$ を部分合併切除して上葉を摘出した. 上縦隔と\#7のリ
ンパ節郭清を行い, 手術終了した。

手術時間 : 5 時間 59 分, 出血量 : $550 \mathrm{ml}$.

病理所見：(1)術前の頸項部皮膚生検：表皮に錯角化を 認め, 真皮浅層に血管周囲性のリンパ球主体の炎症性細 胞浸潤が認められる. 表皮基底層に液状変性を認めた (Fig. 3A).

(2)右上葉 (手術)：最大径 $4.5 \mathrm{~cm}$, 白色充実性腫瘤, 内 部に壊死を認めた。腫瘍は胞巣状に増殖する中分化扁平 上皮癌の像であった (Fig. 3B). リンパ節転移はなく, 下 葉への腫瘍細胞の浸潤も認めず, pT2bN0M0 Stage IIA と診断した.

術後経過 : 術後 3 日目に喀痰排出困難による酸素化不 良を認め, 気管支鏡下吸痰を行った。 その後酸素化は改 善傾向だったが, 労作時の酸素化不良が続き, 在宅酸素 療法を導入して 17 日目に自宅退院した. 皮膚所見に関し ては, 術後 4 日目に頸項部, 鼻尖部, 両側手指の鱗屑と 紅斑が劇的に改善し, 術後 17 日目には耳介と鼻尖部に関 してはほぼ消失した (Fig. 4). 手指の鱗首は残存したもの の, 外用薬にて改善した. 当院皮膚科医師により, 皮疹 の性状と経過から Bazex 症候群と診断された. 現在術後 4 力月再発なく, 皮膚症状も再燃しておらず, 外来で経過 観察している. 

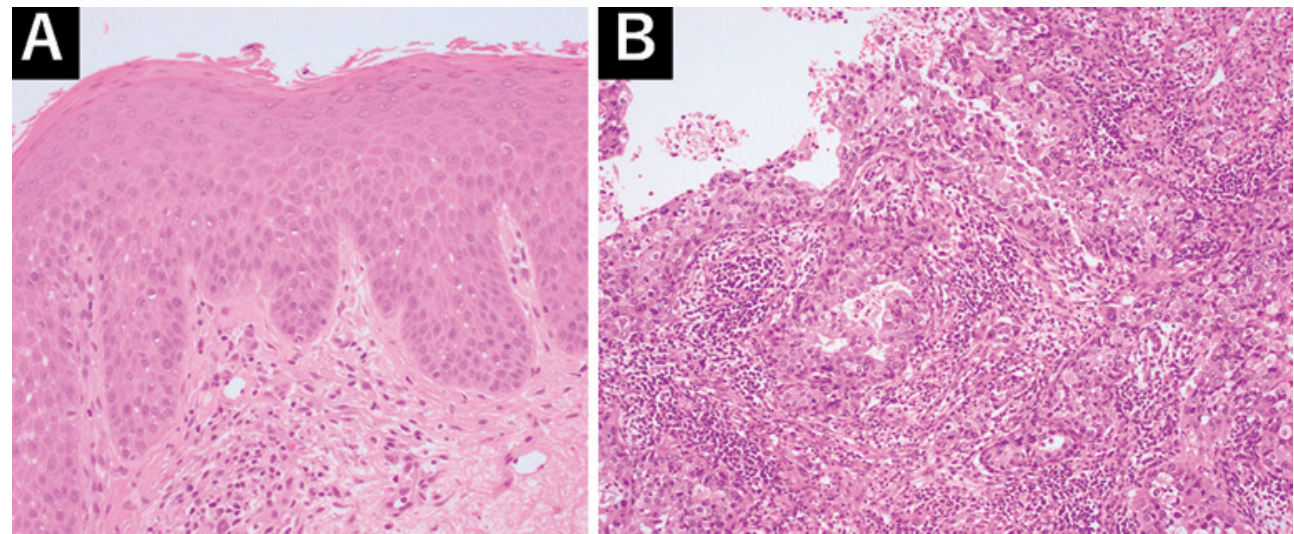

Fig. 3

A: Pathological findings of skin biopsy in the nuchal region show acanthosis and perivascular lymphocyte infiltration. (H-E, $\times 100)$

B: Pathological findings of lung tumor in right upper lobe. There were squamous cell carcinoma cells with moderate differentiated. (H-E, $\times 100)$
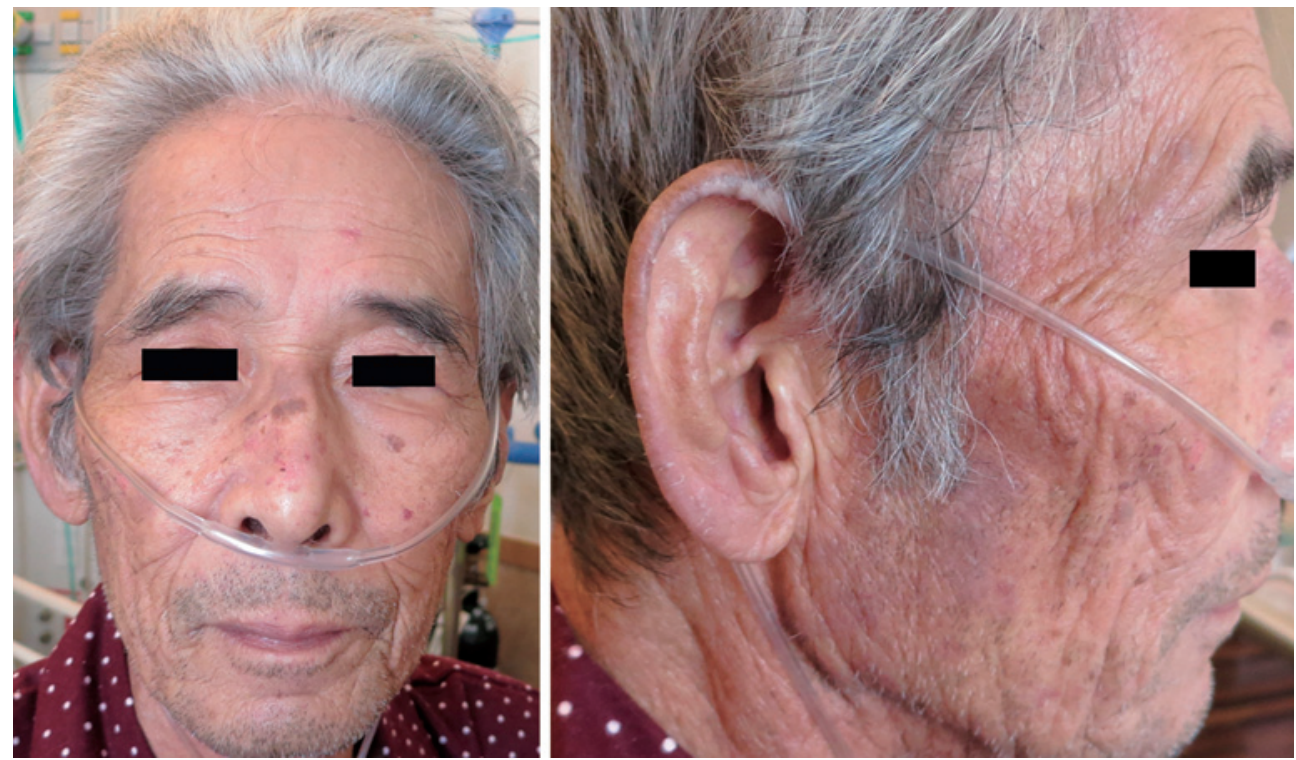

Fig. 4 Skin manifestation after surgery

\section{考察}

Bazex 症候群はまれな病態であり，1965 年に初めて Bazexにより提唱された疾患概念である ${ }^{3}$. Bazex は, (1) 鼻部・耳介・四肢末端部などから始まる過角化性紅斑を 呈する，(240 歳以上の男性に多い，(3)咽頭・喉頭・肺・ 食道に原発する悪性腫瘍である, (4)悪性腫瘍の組織型は 扁平上皮癌が多い，(5)外用薬は無効であり，悪性腫瘍を 治療することにより軽快するという特徴を有すると報告
している4. Bolognia らの報告によると $67 \%$ で腫瘍の発 見よりも皮膚症状が先行しており，臨床所見が重要であ $る^{5}$. 皮膚所見に関しては, 紅斑を伴う角化病変が典型的 である．鱗屑を伴う紅斑で乾癬との鑑別が必要であり， 好発部位は手指や足底，爪，鼻部，前額部，頸部，頭部 である．腫瘍発見に至るまでの期間に関しては，すべて の癌腫を含めた 113 例の検討では, 中央値は 11 力月, 最 大で 72 力月と報告されている5)。このように，皮膚症状 が先行してから腫瘍発見までの期間はかなり長く，発見 
Table 1 Characteristics of lung cancer patients with Bazex syndrome

\begin{tabular}{|c|c|c|c|c|c|c|c|c|c|}
\hline case & age & $\operatorname{sex}$ & $\begin{array}{l}\text { pathol- } \\
\text { ogy }\end{array}$ & The reason for tumor detection & itch & $\begin{array}{l}\text { month } \\
\text { since } \\
\text { tumor } \\
\text { detection }\end{array}$ & $\begin{array}{l}\text { treat- } \\
\text { ment }\end{array}$ & $\begin{array}{l}\text { recur- } \\
\text { rence }\end{array}$ & outcome \\
\hline Crucitti, et al 6) & 55 & M & Ad & $\begin{array}{l}\text { erthematous hyperkeratotic lesions } \\
\text { of fingers }\end{array}$ & no & 42 months & $\mathrm{CT}$ & stage IV & alive \\
\hline Hosokawa, et al 7) & 78 & M & $\mathrm{Sq}$ & hyperkeratosis of finger & yes & 7 months & surgery & no & alive \\
\hline Kobayashi, et al ${ }^{8)}$ & 77 & M & $\mathrm{Sm}$ & hyperkeratosis of fingers and soles & no & 8 months & CRT & yes & dead \\
\hline Saruwatari, et al 9) & 71 & M & $\mathrm{Sq}$ & hyperkeratosis of fingers and soles & no & 8 months & surgery & no & alive \\
\hline Zarzour, et al ${ }^{10)}$ & 58 & $\mathrm{~F}$ & $\mathrm{Sm}$ & $\begin{array}{l}\text { hyperpigmented rash on arms, legs, } \\
\text { and feet }\end{array}$ & no & 32 months & $\mathrm{CT}$ & stage IV & dead \\
\hline Sharma, et al 11) & 63 & $\mathrm{~F}$ & Ad & erthematous plaque of hands & no & 12 months & unknown & unknown & unknown \\
\hline Valdivielso, et al ${ }^{12)}$ & 64 & M & $\mathrm{Sq}$ & hyperkeratosis of fingers and soles & no & 2 months & CRT & yes & alive \\
\hline Fityan, et al 13) & 68 & M & $\mathrm{Sq}$ & hyperkeratosis of fingers and soles & no & 3 months & surgery & no & alive \\
\hline Handfield-Jones, et al 14) & 73 & $\mathrm{~F}$ & $\mathrm{Sq}$ & hyperkeratosis of fingers and toes & no & 3 months & RT & no & alive \\
\hline Handfield-Jones, et al 14) & 73 & M & $\mathrm{Sq}$ & dry scaly skin around nails & no & 2 months & no & stage IV & dead \\
\hline Hoepffner, et al 15) & 66 & M & $\mathrm{Sm}$ & $\begin{array}{l}\text { erythematous hyperkeratosis of fin- } \\
\text { gers }\end{array}$ & no & 2 months & surgery & unknown & alive \\
\hline Rio Ramirez, et al ${ }^{16)}$ & 78 & M & Ad & hyperkeratosis of soles & yes & 4 months & unknown & unknown & unknown \\
\hline Lawrence, et al ${ }^{17)}$ & 71 & M & $\mathrm{Sq}$ & hyperkeratosis of fingers & no & 3 months & surgery & yes & dead \\
\hline Amano, et al 18) & 82 & M & $\mathrm{Sq}$ & $\begin{array}{l}\text { hyperkeratotic erthematous plaque } \\
\text { on palm and soles }\end{array}$ & yes & 6 months & surgery & no & alive \\
\hline Zhao, et al ${ }^{19)}$ & 83 & M & Ad & $\begin{array}{l}\text { erythematous plaque of face, fin- } \\
\text { gers, and feet }\end{array}$ & no & 60 months & $\mathrm{CT}$ & stage IV & alive \\
\hline Strobel et al 20) & 58 & M & $\mathrm{Sq}$ & hyperkeratosis of fingers and toe & no & 0 months & CRT & stage IV & alive \\
\hline our case & 77 & M & $\mathrm{Sq}$ & $\begin{array}{l}\text { erythematous hyperkeratosis of fin- } \\
\text { gers, nuchal and face }\end{array}$ & yes & 38 months & surgery & no & alive \\
\hline
\end{tabular}

M, male; F, female; Ad, adenocarcinoma; Sq, squamous cell carcinoma; Sm, small cell carcinoma; CT, chemotherapy; CRT, chemoradiotherapy

に難渋することも多い.

肺癌領域における Bazex 症候群の頻度は不明である が, Crucitti ら 143 例の検討によると Bazex 症候群全体 で肺癌は 2 番目に多く ${ }^{6}$, 日常診療で遭遇する可能性は十 分にある. 今回, 肺癌の Bazex 症候群と診断された症例 に関して検索を行ったところ，本邦では自験例を含めて 4 例7-9), 海外の報告を含めると全 17 例だった. 10-20). Table $1^{6-20}$ に臨床的特徵をまとめた. 既報の如く, 扁平上皮癌の 割合が多いこと, 腫瘍発見よりも先に皮膚所見で気づか れることが特徵である。また Table $1^{6-20)}$ の検討では皮膚 症状出現後から腫瘍発見に至るまでに要した期間の中央 值が 6 力月，最大 60 カ月であり，自験例のように 36 カ 月以上経過してから見つかることに矛盾はない。腫瘍随 伴性皮膚所見が肺癌の病勢を反映したという症例報告 ${ }^{21)}$ もあり，興味深いが，本症例では徐々に皮膚所見の増悪 を認めていたものの, 術前の胸部レントゲン写真の経過 が不明であり，肺癌の病勢を反映したかに関しては不明 である.
今回の症例にみられた皮膚所見が腫瘍によるものかど うかに関しては議論の余地があるが，1)皮疹の所見は角 化性紅斑であること，2）皮疹の出現部位が耳介・前額 部・鼻部・両側四肢末端であること，3）切除後に皮疹が 速やかに軽快した臨床経過から，今回の皮疹がBazex 症候群によるものと判断した。また術前の病理所見も炎 症性の角化を示すものであり, 非特異的ではあるが,

Bazex 症候群と一致する所見だった。

本疾患群の皮膚症状の発現機序に関しては不明な点が 多いが，ケラチノサイトと腫瘍抗原の交差反応による機 序 ${ }^{6}$, 腫瘍が分泌する物質に対するアレルギー反応, 腫瘍 の産生するサイトカインによる反応，担癌状態に伴う免 疫能低下による感染症7) などが考えられている. Bazex らの報告では搔痒を伴う症例は $18 \%$ 程度であり ${ }^{4)}$, 搔痒 を伴う症例は比較的少ないと報告されているものの，本 症例においても術前に择痒感を認めており, 何らかのア レルギー機序の関与があった可能性がある.

現在術後 4 力月間経過観察中であるが，皮虐所見も正 
常であり，再発なく経過している，皮膚所見が再発発見 の契機になった症例も報告されており ${ }^{17)}$, 再発の早期発 見においても重要な所見である.今後は皮膚所見にも注 目して経過観察することが重要と考える.

\section{結語}

肺癌切除により 3 年以上続いていた角化性紅斑が治癒 したBazex 症候群の 1 例を経験した. 今後も皮膚所見に 注意して経過観察を行う。

\section{利益相反}

\section{本論文について申請する利益相反はない．}

\section{文献}

1. Pelosof LC, Gerber DE. Paraneoplastic syndromes: an approach to diagnosis and treatment. Mayo Clin Proc 2010; 85: 838-54.

2. Thiers BH, Sahn RE, Callen JP. Cutaneous manifestations of internal malignancy. CA Cancer J Clin 2009; 59: 73-98.

3. Bazex A, Salvador R, Dupre A. Hyperkeratosis of the extremities-like paraneoplastic syndrome: Healing after treatment of a larynx epithelioma. Bull Soc Fr Dermatol Syphiligr 1965; 72: 182.

4. Bazex A, Griffiths A. Acrokeratosis paraneoplastica: A new cutaneous marker of malignancy. Br J Dermatol 1980; 103: 301-6.

5. Bolognia JL, Brewer YP, Cooper DL. Bazex syndrome (acrokeratosis paraneoplastica). An analytic review. Medicine (Baltimore) 1991; 70: 269-80.

6. Crucitti A, Feliciani C, Grossi U, La Greca A, Porziella V, Giustacchini P, et al. Paraneoplastic acrokeratosis (bazex syndrome) in lung cancer. J Clin Oncol 2009; 27: e266-8.

7. 細川洋一郎, 中井浩三, 石川絵美子, 横井郁美, 米田耕造, 石井知也, 他. Bazex 症候群の 1 例. 皮䖉臨床 2011; 53: 1281-6.

8. 小林圭介, 志村智恵子, 片桐一元. 肺小細胞癌を合併した Bazex 症候群．皮病診療 2015; 37: 1195-8.

9. 猿渡 浩, 金蔵拓郎, 児浦純生. 肺扁平上皮癌に合併した Bazex 症候群．皮病診療 2012; 34: 281-4.

10. Zarzour JG, Singh S, Andea A, Cafardi JA. Acrokeratosis paraneoplastica (Bazex syndrome): report of a case asso- ciated with small cell lung carcinoma and review of the literature. J Radiol Case Rep 2011; 5: 1-6.

11. Sharma V, Sharma NL, Ranjan N, Tegta GR, Sarin S. Acrokeratosis paraneoplastica (Bazex syndrome): case report and review of literature. Dermatol Online J 2006; 12: 11 .

12. Valdivielso M, Longo I, Suarez R, Huerta M, Lazaro P. Acrokeratosis paraneoplastica: Bazex syndrome. J Eur Acad Dermatol Venereol 2005; 19: 340-4.

13. Fityan A, Haider S, Stephens CJ. Acral violaceous erythema and hyperkeratosis. Clin Exp Dermatol 2011; 36: 320-1.

14. Handfield-Jones SE, Matthews CN, Ellis JP, Das KB, McGibbon DH. Acrokeratosis paraneoplastica of Bazex. J R Soc Med 1992; 85: 548-50.

15. Hoepffner N, Albrecht HP, Haagen G, Diepgen TL, Hornstein OP. A special form of Bazex acrokeratosis in small cell bronchial cancer. Hautarzt 1992; 43: 496-9.

16. Rio Ramirez MT, Casado Lopez ME, Peiron Puyal MJ, Penas Herrero JM. Pulmonary adenocarcinoma and Bazex syndrome (paraneoplastic acrokeratosis). Arch Bronconeumol 2007; 43: 46-8.

17. Lawrence N, Rietschel RL, Butcher RB 2nd. A palmar dermatosis linked to occult carcinoma of the upper thorax, head and neck: Bazex's syndrome and tripe palm. Laryngoscope 1990; 100: 1323-5.

18. Amano M, Hanafusa T, Chikazawa S, Ueno M, Namiki T, Igawa K, et al. Bazex Syndrome in Lung Squamous Cell Carcinoma: High Expression of Epidermal Growth Factor Receptor in Lesional Keratinocytes with Th2 Immune Shift. Case Rep Dermatol 2016; 8: 358-62.

19. Zhao J, Zhang X, Chen Z, Wu JH. Case Report: Bazex Syndrome Associated With Pulmonary Adenocarcinoma. Medicine (Baltimore) 2016; 95: e2415.

20. Strobel ES, Bouveret C, Kohl PK. Acrokeratosis paraneoplastica of Bazex as an indicator for underlying squamous cell carcinoma of the lung. J Cancer Res Clin Oncol 2006; 132: 376-8.

21. 鎌田稔子, 稲福和宏, 飯田智彦, 藤原大樹, 長門 芳, 柴 光年. 再発時に腫瘍随伴性皮膚病変を認めた肺腺癌の 1 例. 肺癌 2012; 52: 1057-63. 


\title{
Cure of hyperkeratotic dermatitis by complete lung cancer resection: A case report
}

\author{
Shuihchi Shinohara*1, Takamitsu Onitsuka*1, Fujiko Fukatsu*2 \\ Kazuhiko Machida*3, Masaki Matsuo*3, Masakazu Sugaya*1 \\ ${ }^{* 1}$ Department of Thoracic Surgery, ${ }^{* 2}$ Department of Dermatology, ${ }^{* 3}$ Department of Pulmonary \\ and Respiratory Medicine, Chubu Rosai Hospital, Nagoya, Aichi, Japan
}

A 77-year-old man with erythematous hyperkeratotic skin lesions on his fingers, face, and neck for more than 3 years presented to our hospital for the purpose of surgery to excise non-small cell lung cancer in the right upper lobe. He underwent right upper lobectomy, and then erythematous hyperkeratotic lesions markedly improved on postoperative day 4 and were cured 2 months after surgery. We finally diagnosed his skin lesions as Bazex syndrome. He has not shown the recurrence of the skin manifestations or lung cancer for four months.

(C) The Japanese Association for Chest Surgery (JACS) 